\title{
EFFECTS OF DIFFERENT NITROGEN LEVELS ON THE GRAIN YIELD AND SOME YIELD COMPONENTS OF QUINOA (Chenopodium quinoa Willd.) UNDER MEDITERRANEAN CLIMATIC CONDITIONS
}

\author{
Hakan GEREN \\ Ege University, Faculty of Agriculture, Dept. of Field Crops, Izmir, TURKEY \\ Corresponding author: hakan.geren@ege.edu.tr
}

Received: 12.02.2015

\begin{abstract}
Quinoa (Chenopodium quinoa Willd.), is a pseudo-cereal crop that has been cultivated in the Andean region in South America. The quinoa as a field crop has a great potential in the improvement of food for humans and animals even under the conditions of marginal lands. For getting high crop yields, nutrients in balanced amount are a basic requirement. Experiments were carried out at the Bornova experimental fields of Field Crops Dept. of Agriculture Fac., Ege Univ., Turkey during 2013 and 2014 main crop growing season in order to evaluate the effect of seven nitrogen levels $\left(0,50,75,100,125,150\right.$ and $\left.175 \mathrm{~kg} \mathrm{ha}^{-1}\right)$ on the grain yield and some yield components of cultivar Q-52 of quinoa. Results indicated that the effects of nitrogen treatments and years on all characteristics tested were significant. Nitrogen level of $150 \mathrm{~kg} \mathrm{ha}^{-1}$ was proved to be the best level for nitrogen supplementation of soil for grain yield $\left(2.95 \mathrm{t} \mathrm{ha}^{-1}\right)$ and crude protein content (16\%) of quinoa under Mediterranean ecological conditions of Bornova.
\end{abstract}

Key words: quinoa, Chenopodium quinoa, nitrogen level, grain yield.

\section{INTRODUCTION}

Quinoa (Chenopodium quinoa Willd.) member of Chenopodiaceae family is a seed crop that has been cultivated for thousands of years in the Andean region for its nutritious grain and leaves (Pearsall, 1992). It is an annual broad-leaved plant, also adaptable to the conditions of marginal lands (Rea et al., 1979), allotetraploid $(2 \mathrm{n}=4 \mathrm{x}=36)$ (Simmonds, 1971), 1-2 $\mathrm{m}$ tall with deep penetrating roots and can be cultivated from sea level to over $4000 \mathrm{~m}$ above sea level (Jacobsen, 2003). The crop, a pseudo-cereal, contains gluten-free high-quality protein, so it can play an important role in the diet of people suffering from celiac disease (Kuhn et al., 1996; Doweidar and Kamel, 2011). The protein of quinoa seed is rich in essential amino acids, particularly methionine, threonine and lysine, which are the limiting amino acids in most cereal grains (Bhargava et al., 2007; Comai et al., 2007). The Organization of the United Nations for Food and Agriculture (FAO) has declared the year 2013 as the year of quinoa (Anonymus, 2013.).

Preliminary success of quinoa cultivation in Turkey has opened the avenues to explore the production potential of quinoa comprehensively (Ince Kaya, 2010). Quinoa can be successfully grown on marginal soils showing its very low nutrient requirements (Jacobsen, 2003). However, quinoa is also highly responsive to soil nitrogen (Erley et al., 2005; Gomaa, 2013). Basra et al. (2014) also stated that nitrogen level of $75 \mathrm{~kg} \mathrm{~N} \mathrm{ha}^{-1}$ was proved to be optimum level for nitrogen supplementation of soil for quinoa growth and development to harvest maximum economic yield under ecological conditions of Egypt.

The use of modern commercial fertilizers in agricultural production results in increased crop yields in addition to the effect of better plant nutrition through commercial fertilizers signify themselves not only in increasing yields, but also in an increase in the total biomass production (Finck, 1982). Erley et al. (2005) evaluated the response of quinoa to nitrogen fertilization rates of 0,80 and $120 \mathrm{~kg} \mathrm{~N} \mathrm{ha}^{-1}$, the results evidenced that quinoa responded strongly to nitrogen fertilization and quinoa yielded between 1.8 and $3.5 \mathrm{t} \mathrm{ha}^{-1}$.

A nitrogen fertilization requirement of quinoa crop is still under study world widely because of variability of ecological conditions. For instance, Erley et al. (2005) reported that quinoa responded well to nitrogen and achieved yield up to $350 \mathrm{~kg} \mathrm{ha}^{-1}$ at $120 \mathrm{~kg} \mathrm{~N} \mathrm{ha}^{-1}$, grain yield boosted by $94 \%$ as compared to control. However, Jacobsen et al. (1994) found increase in yield (averaging $12 \%$ ) at 80 to $120 \mathrm{~kg} \mathrm{~N} \mathrm{ha}^{-1}$. Quinoa responds to nitrogen application by not only increase the crop growth and yield 
but also the quality of grain. Thanapornpoonpong (2004) explored the significant effect of different nitrogen rates $\left(0,0.8\right.$ and $1.2 \mathrm{~g} \mathrm{~N}$ pot $\left.^{-1}\right)$ on plant height, grain yield per plant, harvest index, thousand kernel weight, protein content of seed and amino acid profile of amaranth and quinoa.

Jacobsen et al. (1994) found that quinoa grain yield increased with the increasing nitrogen fertilization rate from 40 to $160 \mathrm{~kg} \mathrm{~N} \mathrm{ha}^{-1}$. Shams (2012) studied the response of quinoa to five nitrogen fertilization levels of $0,90,180,270$ and $360 \mathrm{~kg} \mathrm{ha}^{-1}$. The author found clearly that grain and biological yields increased gradually with increasing nitrogen levels up to the highest level. Gomaa (2013) informed that the growth traits, seed yield and seed quality of quinoa plant can be improved by the application of inorganic and biofertilizers (nitrobin or phosphorin). Kakabouki et al. (2014) stated that there were significant differences in quinoa crude protein $(\mathrm{CP})$ content among fertilizer treatments $\left(2000 \mathrm{~kg} \mathrm{ha}^{-1}\right.$ cow manure, 100 and $200 \mathrm{~kg} \mathrm{~N} \mathrm{ha}^{-1}$ ) and all fertilization treatments resulted in values higher than those of the control and, the highest $\mathrm{CP}$ content $(27 \%)$ in quinoa was observed for $200 \mathrm{~kg} \mathrm{~N} \mathrm{ha}^{-1}$ application.

Quinoa is a native field crop to Latin America which has the potential to grow with fewer inputs, water and tolerate a variety of biotic and abiotic stresses as compared to common cereals (Rea et al., 1979; Basra et al., 2014), and is a new introduction to Turkey. Therefore, getting to know the possibility of production of this crop is important not only in Turkey, but also in all over the world. Nevertheless, information on the productivity and quality of quinoa crop under intensive farming management in Mediterranean environment is not well documented. The objective of this experiment was to determine the optimum level of nitrogen fertilizer for getting maximum grain yield of quinoa (Chenopodium quinoa Willd.) under Mediterranean climatic conditions.

\section{MATERIALS AND METHODS}

\section{Location of Experiment}

The experiment was carried out during 2013 and 2014 growing season at Bornova experimental area $\left(38^{\circ} 27.236\right.$ $\mathrm{N}, 27^{\circ} 13.576$ E) in Agricultural Faculty of Ege University, Izmir, Turkey, at about $20 \mathrm{~m}$ above sea level with typical Mediterranean climate characteristics (Table 1). Experimental area is located in the Mediterranean zone of the country with quite mild winters and hot summers. Field studies were started in mid spring with low air temperature and satisfactory moisture levels were experienced in the germination and emergence period of relatively small seeds in both years, therefore, stands were excellent. The soil was a silty-clay loam (30.6\% clay, $36.7 \%$ silt, and $32.7 \%$ sand) with $\mathrm{pH} 7.32$, organic matter $1.16 \%$, salt $0.074 \%, 0.123 \%$ total $\mathrm{N}$, available phosphorus (1.4 ppm) and available potassium (350 ppm).

Table 1. Some meteorological parameters of experimental area at Bornova in 2013 and 2014.

\begin{tabular}{|c|c|c|c|c|c|c|c|c|c|}
\hline \multirow[b]{2}{*}{ Months } & \multicolumn{3}{|c|}{ Average temperature $\left({ }^{\circ} \mathrm{C}\right)$} & \multicolumn{3}{|c|}{ Total precipitation (mm) } & \multicolumn{3}{|c|}{ Relative humidity (\%) } \\
\hline & 2013 & 2014 & LYA & 2013 & 2014 & LYA & 2013 & 2014 & LYA \\
\hline April & 17.3 & 17.0 & 16.1 & 30.2 & 132.2 & 46.4 & 54.0 & 60.6 & 62.9 \\
\hline May & 22.7 & 20.8 & 21.0 & 43.7 & 15.3 & 25.4 & 54.7 & 57.0 & 59.6 \\
\hline June & 25.7 & 25.0 & 26.0 & 27.1 & 48.5 & 7.5 & 50.7 & 53.0 & 52.9 \\
\hline July & 28.4 & 27.8 & 28.3 & 0.0 & 1.0 & 2.1 & 42.0 & 49.9 & 51.2 \\
\hline $\mathbf{X}-\Sigma$ & 23.6 & 22.7 & 22.9 & 101.0 & 197.0 & 81.4 & 50.4 & 55.1 & 56.7 \\
\hline
\end{tabular}

LYA:Long year average, $\mathbf{X}$ : mean, $\Sigma$ :total

\section{Field applications and experimental design}

Q-52 cultivar of quinoa (Chenopodium quinoa Willd.) was used as crop material. The experiment was carried out with a randomized complete block design with three replicates; seven different nitrogen levels $(0,50,75,100$, 125,150 and $175 \mathrm{~kg} \mathrm{ha}^{-1}$ ) were tested on quinoa crop. Seeds were sown by hand in rows $35 \mathrm{~cm}$ apart at a depth of 2-3 cm on 8th of April 2013 and 7th of April 2014 at a rate of $20 \mathrm{~kg} \mathrm{ha}^{-1}$ (Jacobsen, 2003). Each plot was consisted of 6 rows with $5 \mathrm{~m}$ length $\left(10.5 \mathrm{~m}^{-2}\right)$. Half a dose of nitrogen fertiliser (urea) was applied before sowing, and the rest of nitrogen was applied at 7-10 leaf stage as $\mathrm{NH}_{4} \mathrm{NO}_{3}$. All plots even control were fertilised using $100 \mathrm{~kg} \mathrm{ha}^{-1} \mathrm{P}_{2} \mathrm{O}_{5}$ before sowing (Jacobsen et al., 1994).

Following establishment, plants were hand-thinned to 9-10 $\mathrm{cm}$ apart on rows so that the final populations were 28.6 plants $\mathrm{m}^{-2}$. Overhead sprinkler system was installed on the field during the both growing seasons. No insecticide was used to control insects. Hand hoeing was done once after emergence and fluazifop-p-butyl (500 g $\mathrm{ha}^{-1}$ of a.i.) was applied at 3-5 leaf stage of crops to control narrow leafed weeds in both years.

\section{Measurements}

Plants shoots were harvested at maturity stage $(\sim 13 \%$ moisture) during July in both years, collecting mid 4 rows of plots in order to avoid border effects (net $5.6 \mathrm{~m}^{-2}$ ). 30 plants from the central rows in each replication were randomly tagged and data were recorded on these plants for the following traits (Bhargava et al., 2007): Plant height $(\mathrm{cm})$ : the average height from the ground level to the tip of the inflorescence on the main stem at the time of harvesting was measured. Dry weight $\left(\mathrm{g} \mathrm{plant}^{-1}\right)$ : sample plants excluding the roots, inflorescence, branches and leaves were air dried and weighted. Harvest index (\%): This was calculated by the following formula: HI: (grain yield plant $\left.^{-1}\right) /\left(\right.$ dry weight plant $\left.{ }^{-1}\right)$. Thousand seed weight (g): A sample of 1000 seeds from the bulked seed of each 
plot was weighed. Grain yield $\left(\mathrm{kg} \mathrm{ha}^{-1}\right)$ : The seed of all the crops of each plot were bulked, after threshing by a stationary thresher, weighed and the grain yield/plot was then converted to $\mathrm{kg}$ per hectare. Crude protein content (\%) of seed was determined using the Kjeldahl method $(\mathrm{N} \%)$ with a conversion factor of 6.25 .

\section{Statistical analysis}

All data were statistically analyzed using analysis of variance (ANOVA) with the Statistical Analysis System (SAS, 1998). Probabilities equal to or less than 0.05 were considered significant. If ANOVA indicated differences between treatment means a LSD test was performed to separate them (Stell et al., 1997).

\section{RESULTS AND DISCUSSION}

The results are summarized in Table 2. The year and nitrogen level effects were the main sources of variation in all characters tested, while the interactions $(\mathrm{YxN})$ were not significant for harvest index, thousand grain weight and $\mathrm{CP}$ content of seed.

Table 2. Effect of different nitrogen levels on the yield and some yield components of quinoa.

\begin{tabular}{|c|c|c|c|c|c|c|}
\hline \multirow[b]{2}{*}{ N levels $\left(h^{-1}\right)$} & 2013 & 2014 & Mean & 2013 & 2014 & Mean \\
\hline & \multicolumn{3}{|c|}{-------- Plant height (cm) -------- } & \multicolumn{3}{|c|}{----- Grain yield $\left(\right.$ g plant $\left.^{-1}\right)$-.--- } \\
\hline $0 \mathrm{~kg}$ & 43.8 & 53.1 & 48.5 & 2.4 & 3.3 & 2.9 \\
\hline $50 \mathrm{~kg}$ & 48.4 & 58.9 & 53.6 & 4.1 & 5.0 & 4.5 \\
\hline $75 \mathrm{~kg}$ & 57.1 & 72.2 & 64.6 & 6.1 & 6.1 & 6.1 \\
\hline $100 \mathrm{~kg}$ & 66.2 & 75.1 & 70.7 & 8.7 & 8.4 & 8.6 \\
\hline $125 \mathrm{~kg}$ & 77.1 & 80.4 & 78.7 & 9.2 & 10.0 & 9.6 \\
\hline $150 \mathrm{~kg}$ & 82.8 & 93.0 & 87.9 & 9.2 & 11.2 & 10.2 \\
\hline $175 \mathrm{~kg}$ & 87.1 & 101.1 & 94.1 & 7.9 & 9.1 & 8.5 \\
\hline Mean & 66.1 & 76.2 & 71.2 & 6.8 & 7.6 & 7.2 \\
\hline \multirow[t]{2}{*}{$\operatorname{LSD}(.05)$} & $\mathrm{Y}: 1.8 \mathrm{~N}: 3.4$ & YxN:4.8 & & Y:0.2 N:0.3 & YxN:0.5 & \\
\hline & \multicolumn{3}{|c|}{----- Harvest index $(\%)$} & \multicolumn{3}{|c|}{---- Thousand grain weight $(\mathrm{g})$} \\
\hline $0 \mathrm{~kg}$ & 12.3 & 14.4 & 13.3 & 3.38 & 3.33 & 3.36 \\
\hline $50 \mathrm{~kg}$ & 15.8 & 19.6 & 17.7 & 3.34 & 3.26 & 3.30 \\
\hline $75 \mathrm{~kg}$ & 34.4 & 36.8 & 35.6 & 3.28 & 3.18 & 3.23 \\
\hline $100 \mathrm{~kg}$ & 43.2 & 44.6 & 43.9 & 3.28 & 3.14 & 3.21 \\
\hline $125 \mathrm{~kg}$ & 43.6 & 46.2 & 44.9 & 3.21 & 3.11 & 3.16 \\
\hline $150 \mathrm{~kg}$ & 44.6 & 48.5 & 46.6 & 3.13 & 3.06 & 3.10 \\
\hline $175 \mathrm{~kg}$ & 38.8 & 41.4 & 40.1 & 3.11 & 3.04 & 3.08 \\
\hline Mean & 33.3 & 35.9 & 34.6 & 3.25 & 3.16 & 3.20 \\
\hline \multirow[t]{2}{*}{$\mathrm{LSD}(.05)$} & $\mathrm{Y}: 0.7 \quad \mathrm{~N}: 1.3$ & YxN:ns & & Y:0.03 N:0.05 & 5 YxN:ns & \\
\hline & \multicolumn{3}{|c|}{--.- Grain yield $\left(\mathrm{kg} \mathrm{ha}^{-1}\right)$} & \multicolumn{3}{|c|}{---- CP content of seed $(\%)$} \\
\hline $0 \mathrm{~kg}$ & 867 & 988 & 927 & 8.2 & 7.6 & 7.9 \\
\hline $50 \mathrm{~kg}$ & 1190 & 1490 & 1340 & 9.8 & 8.3 & 9.1 \\
\hline $75 \mathrm{~kg}$ & 1855 & 1936 & 1896 & 12.1 & 10.0 & 11.1 \\
\hline $100 \mathrm{~kg}$ & 2378 & 2513 & 2446 & 14.5 & 11.7 & 13.1 \\
\hline $125 \mathrm{~kg}$ & 2675 & 2939 & 2807 & 15.4 & 14.2 & 14.8 \\
\hline $150 \mathrm{~kg}$ & 2599 & 3308 & 2953 & 16.1 & 15.5 & 15.8 \\
\hline $175 \mathrm{~kg}$ & 2361 & 2677 & 2519 & 17.1 & 16.0 & 16.5 \\
\hline Mean & 1989 & 2264 & 2127 & 13.3 & 11.9 & 12.6 \\
\hline $\operatorname{LSD}(.05)$ & $\mathrm{Y}: 32 \quad \mathrm{~N}: 59$ & YxN:84 & & $\mathrm{Y}: 0.5 \quad \mathrm{~N}: 0.9$ & YxN:ns & \\
\hline
\end{tabular}

$\mathrm{Y}$ : year, $\mathrm{N}$ : nitrogen, $\mathrm{YxN}$ : interaction, ns: not significant.

\section{Plant height}

The plant height was affected by $\mathrm{YxN}$ interaction. The highest plant height $(101.1 \mathrm{~cm})$ was obtained from $175 \mathrm{~kg}$ $\mathrm{N}$ ha $^{-1}$ application in 2014, whereas the lowest was 43.8 $\mathrm{cm}$ for $0 \mathrm{~kg} \mathrm{~N} \mathrm{ha}^{-1}$ application in 2013 (Table 2). Year effect was also significant and average quinoa height of second year $(76.2 \mathrm{~cm})$ was higher than the first year $(66.1$ $\mathrm{cm}$ ) due to the total precipitation of the second year which was clearly higher than first year (Table 1).

In our study, the plant height of quinoa increased noticeably by increasing nitrogen fertilizer rate up to 175 $\mathrm{kg} \mathrm{N} \mathrm{ha}^{-1}$ in both seasons. Many researchers informed that the plant height of quinoa increases with the increasing nitrogen level are mainly due to the role of nitrogen in stimulating metabolic activity which contribute to the increase in metabolites amount and consequently lead to internodes elongation and increase plant height with the increasing nitrogen rate (Jacobsen et al., 1994, Erley et al., 2005; Shams, 2012). Jacobsen et al. (1994) expressed that plant height of quinoa increased with increasing $\mathrm{N}$ fertilization rate from 40 to $160 \mathrm{~kg} \mathrm{~N} \mathrm{ha}^{-1}$. Shams (2012) found clearly that plant height in quinoa increased gradually with increasing nitrogen levels up to $360 \mathrm{~kg} \mathrm{~N}$ $\mathrm{ha}^{-1}$. Our findings are in accordance with those researcher's results. 


\section{Grain yield per plant}

The nitrogen $\mathrm{x}$ year interaction was highly significant on the grain yield per plant (Table 2). The highest grain yield (11.2 $\mathrm{g} \mathrm{plant}^{-1}$ ) was obtained from $150 \mathrm{~kg} \mathrm{~N} \mathrm{ha}^{-1}$ level in the second year, whereas the lowest yield $(2.4 \mathrm{~g}$ plant $^{-1}$ ) was recorded in control plots in the first year. Year effect was also significant and average grain yield per plant of second year (7.6 g) was higher than the first year $(6.8 \mathrm{~g})$, most probably due to the average monthly temperatures in the study site which was consistent with the 20-year average, providing better humidity and precipitation for the maturation of crops in 2014 compared to 2013 (Table 1).

Increases were significant among the nitrogen fertilizer rates till $125 \mathrm{~kg} \mathrm{~N} \mathrm{ha}^{-1}$, but there was not any significant difference between 125 and $150 \mathrm{~kg} \mathrm{~N} \mathrm{ha}^{-1}$ in 2013 season, while the increases were significant among the nitrogen rates till $150 \mathrm{~kg} \mathrm{~N} \mathrm{ha}^{-1}$ in 2014 . In the study, the results of two years average monitored that increased nitrogen levels from 0 to $150 \mathrm{~kg} \mathrm{~N}^{-1}$ increased grain yield per plant but later on decreased. Shams (2012) informed that grain yield per plant in quinoa increased gradually $(1 \mathrm{~g}$ to $10 \mathrm{~g}$ plant $\left.{ }^{1}\right)$ with increasing nitrogen levels up to $360 \mathrm{~kg} \mathrm{~N} \mathrm{ha}^{-1}$. The possible reasons may be the difference in agro-ecological conditions and quinoa genotypes regarding maturation period.

\section{Harvest index}

The nitrogen $\mathrm{x}$ year interaction effect was not significant on harvest index. The highest average harvest index $(46.6 \%)$ was obtained from $150 \mathrm{~kg} \mathrm{~N}^{-1}$ treatment, whereas the lowest (13.3\%) was in control (Table 2). Year effect was also significant on harvest index and average value of first year $(33.3 \%)$ was lower than the second year $(35.9 \%)$.

In the present study, the harvest index of quinoa increased by increasing nitrogen treatments till $150 \mathrm{~kg} \mathrm{~N}$ $\mathrm{ha}^{-1}$ level but later on decreased. Erley et al. (2005) stated that harvest index of quinoa $(31 \%)$ was not affected by nitrogen fertilization from 0 to $120 \mathrm{~kg} \mathrm{ha}^{-1}$. Basra et al. (2014) informed that harvest index increased by increasing nitrogen treatments from 0 to $100 \mathrm{~kg} \mathrm{~N}^{-1}$ level but later decreased at $120 \mathrm{~kg} \mathrm{~N} \mathrm{ha}^{-1}$ level. The increases in harvest index of quinoa with increasing nitrogen levels are mainly due to the role of $\mathrm{N}$ in stimulating metabolic activity which contributed to the increase in metabolites amount most of which is used building yield and its components (Shams, 2012).

The productive capacity of any crop plant depends, not only on its photosynthetic efficiency, but also on the effective translocation of assimilates to the seeds, which is measured by the harvest index. This partitioning between vegetative and reproductive parts can be modified by agronomic practices such as sowing date, plant density, fertilization and irrigation, etc (Bertero et al., 2004; Bhargava et al., 2007). In our study, harvest index presented tremendous variability and ranged from $12.3 \%$ to $48.5 \%$ and being affected by nitrogen levels. However, this range is quite narrow as compared to the report of Rojas et al. (2003) who reported harvest index in quinoa in the range from $6 \%$ to $87 \%$. Our findings were in agreement with some researchers (Bertero et al., 2004; Erley et al., 2005 and Shams, 2012), and the findings displayed that application of $150 \mathrm{~kg} \mathrm{~N} \mathrm{ha}^{-1}$ was the optimum level for nitrogen supplementation of soil for quinoa growth under the ecological conditions of Bornova region.

\section{Thousand grain weight}

The nitrogen $\mathrm{x}$ year interaction was also not significant on thousand grain weight. The highest average thousand grain weight of quinoa (3.36 g) was measured in control plot, whereas the lowest $(3.08 \mathrm{~g})$ was in $175 \mathrm{~kg} \mathrm{~N} \mathrm{ha}^{-1}$ treatment (Table 2). Year effect was also significant on this treat and average value of the first year $(3.25 \mathrm{~g})$ was higher than the second year (3.16 g).

In this study, increasing nitrogen levels caused a limited but significant decrease on thousand grain weight in both growing season. Basra et al. (2014) stated that thousand grain weight of quinoa $(2.1 \mathrm{~g})$ was not affected by nitrogen fertilization from 0 to $120 \mathrm{~kg} \mathrm{ha}^{-1}$. In contrast, another study showed that thousand grain weight of $1.77 \mathrm{~g}$ was the highest after application of $0.8 \mathrm{~g} \mathrm{~N}$ per pot, with increasing nitrogen level to $1.2 \mathrm{~g} \mathrm{~N}$ per pot it was decreased to $1.58 \mathrm{~g}$ (Thanapornpoonpong, 2004). Studies in abroad also showed that nitrogen level has little effect on thousand grain weight (Gomaa, 2013). Gomaa (2013) informed that nitrogen fertilizers application with nitrobin increased the average thousand grain weight from 0 (3.3 g) to $119(4.9 \mathrm{~g}) \mathrm{kg} \mathrm{N} \mathrm{ha}^{-1}$, however, no significant effect was determined between 119 or $238(4.7 \mathrm{~g}) \mathrm{kg} \mathrm{N} \mathrm{ha}^{-1}$, and the highest nitrogen level (357 kg ha ${ }^{-1}$ ) was $3.3 \mathrm{~g}$. Our findings partially confirmed those researcher's results.

\section{Grain yield}

There was significant nitrogen $\mathrm{x}$ year interactions on the grain yield of quinoa. Grain yield in quinoa crops ranged from $867 \mathrm{~kg}$ to $3308 \mathrm{~kg} \mathrm{ha}^{-1}$ in both growing season (Table 2). There were significant differences between nitrogen treatments concerning the yield. The highest grain yield $\left(3308 \mathrm{~kg} \mathrm{ha}^{-1}\right)$ was found in the second year at $150 \mathrm{~kg} \mathrm{~N}^{-1}$ level, whereas the lowest yield (867 $\mathrm{kg} \mathrm{ha}^{-1}$ ) was in the first year at control plot. Year effect was also significant indicating better humidity conditions for the maturation of crops in 2014 compared to 2013, and, average grain yield of quinoa in the second year $\left(2264 \mathrm{~kg} \mathrm{ha}^{-1}\right)$ was higher than the first year $\left(1989 \mathrm{~kg} \mathrm{ha}^{-}\right.$ $\left.{ }^{1}\right)$.

In our study, the grain yield of quinoa increased with the increasing nitrogen level from 0 to $125 \mathrm{~kg} \mathrm{~N}^{-1}$ in the first year, however, the $150 \mathrm{~kg} \mathrm{~N} \mathrm{ha}^{-1}$ treatment caused the highest grain yield compared with the other $\mathrm{N}$ treatments in the second year, whereas rate of increase diminished the grain yield at the highest (175 kg N ha ${ }^{-1}$ ) rates in both years. These results could be explained by the increasing vegetative growth and decreasing inflorescence due to the nitrogen application. Some 
researchers (Erley et al., 2005; Bhargava et al., 2006) explained that plant height, maturation period and yield of quinoa and amaranth increased under optimum soil conditions, but at high levels of nitrogen fertilizer, grain yield was decreased caused by plant lodging. On the contrary, lodging was not observed in our experiment in both years.

According to the two years results, the grain yield was enhanced to $357 \%$ at $150 \mathrm{~kg} \mathrm{~N}^{-1}$ compared to control (0 $\mathrm{kg} \mathrm{N} \mathrm{ha}^{-1}$ ) in the study. Erley et al. (2005) stated that grain yield of quinoa was affected by nitrogen fertilization from 0 to $120 \mathrm{~kg} \mathrm{ha}^{-1}$ being $1790 \mathrm{~kg}$ to $3495 \mathrm{~kg} \mathrm{ha}^{-1}$. Jacobsen et al. (1994) informed that there was a significant grain yield increase when the amount of nitrogen fertilizer was increased from 40 to $160 \mathrm{~kg} \mathrm{~N} \mathrm{ha}^{-1}$ and, the yield decreased by $24-1 \%$ when the nitrogen supply was reduced from 160 to $40 \mathrm{~kg} \mathrm{~N} \mathrm{ha}^{-1}$, while the yield decrease was $120 \mathrm{~kg} \mathrm{~N} \mathrm{ha}^{-1}$ and $2-7 \%$ when the nitrogen supply was reduced to 80 and $120 \mathrm{~kg} \mathrm{~N} \mathrm{ha}^{-1}$, respectively. In addition, Shams (2012) reported that the increases in quinoa grain yield per hectare with the increase in $\mathrm{N}$ fertilizer application from 90 up to $360 \mathrm{~kg} \mathrm{~N}^{-1}$ over the control treatment were $518 \%, 769 \%, 936 \%$ and $1394 \%$ in average of both years. Gomaa (2013) informed that the application of 0,119 and $238 \mathrm{~kg} \mathrm{~N} \mathrm{ha}^{-1}$ with biofertilizers led to consistent increase the grain yield per hectare of quinoa as compared with untreated plants (control) over the years. Kakabouki et al. (2014) reported that nitrogen fertilization increased also the grain yield of quinoa under different tillage system.

\section{Crude protein content of seed}

The nitrogen $\mathrm{x}$ year interaction was not significant on protein content of quinoa seed. The highest average crude protein content $(16.5 \%)$ recorded at $175 \mathrm{~kg} \mathrm{~N}^{-1}$ level, whereas the lowest protein content was $7.9 \%$ in untreated plants (control plot). Mean CP content was significantly higher in $2013(13.3 \%)$ than in 2014 (11.9\%).

The two years average indicated that nitrogen fertilization practices affected CP content of quinoa grain significantly for both years. CP content in grain was progressively increased with the increasing levels of nitrogen up to $175 \mathrm{~kg} \mathrm{~N}^{-1}$. The highest $\mathrm{CP}$ content in the grain recorded by $175 \mathrm{~kg} \mathrm{~N} \mathrm{ha}^{-1}$ treatment which was $16.5 \%$ higher than that in the control treatment, but statistically similar to $150 \mathrm{~kg} \mathrm{~N} \mathrm{ha}^{-1}$ treatment $(15.8 \%)$. The higher protein content at higher nitrogen levels was mainly due to the structural role of nitrogen in building up amino acids (Finck, 1982; Bhargava et al., 2006; Miranda et al., 2013). The progressive increase in protein contents of quinoa seed with the increasing nitrogen rates were also reported by many research workers (Jacobsen et al., 1994; Erley et al., 2005; Shams, 2012).

Erley et al. (2005) informed that average CP content of quinoa cultivars (Faro and Cochabamba) increased gradually $(12.3 \%$ to $14.6 \%$, respectively) with the increasing nitrogen levels from $0 \mathrm{~kg} \mathrm{~N}$ to $120 \mathrm{~kg} \mathrm{~N}^{-1}$ and, Miranda et al. (2013) reported an average CP content of $18.8 \%$ using cold resistance quinoa cultivars (Regalona
Baer and Villarrica). Kakabouki et al. (2014) also stated that increasing nitrogen level increased $\mathrm{CP}$ content of quinoa from $7 \%$ to $27 \%$ under different tillage system. These results in various references were slightly higher than what we were able to determine in our ecology, which might be due to differences in soil texture, crop cultivars and environmental conditions.

The major fact that determines the grain protein content is nitrogen availability, and quinoa is highly responsive to nitrogen fertilizer (Basra et al., 2014) and higher CP content, in a crop with high yield, can be obtained just by application of higher nitrogen quantities.

\section{CONCLUSION}

To come to conclusion, it should be emphasized that quinoa, a new introduction to the Mediterranean coastal part of Turkey is a promising crop material with an acceptable level of adaptability and grain yield pecularities, considering the potential harsh effect of global warming in near future. The results of our two-year study testing the effect of seven different nitrogen levels $\left(0,50,75,100,125,150\right.$ and $\left.175 \mathrm{~kg} \mathrm{ha}^{-1}\right)$ on quinoa crop showed that it was possible to produce an average of 2.95 $\mathrm{t} \mathrm{ha}^{-1}$ quinoa grain yield with an average of $16 \%$ crude protein content under $150 \mathrm{~kg} \mathrm{~N} \mathrm{ha}^{-1}$ treatment in the regions with Mediterranean-type climates. Future experiments on quinoa crop should be conducted at different locations with various agronomical treatments and additional fertilizer rates to be sure that results are relatively consistent over time.

\section{LITERATURE CITED}

Anonymus. 2013. Cereal's of mother: Quinoa, Journal of Tubitak Sci. \& Tech., June 2013, 547:34-35.

Basra,S.M.A., S.Iqbal and I.Afzal. 2014. Evaluating the response of nitrogen application on growth, development and yield of quinoa genotypes, International Journal of Agriculture \& Biology, 16(5):886-892.

Bertero,H.D., A.J.de la Vega, G.Correa, S.E.Jacobsen and A.Mujica. 2004. Genotype and genotype-by-environment interaction effects for grain yield and grain size of quinoa (Chenopodium quinoa Willd.) as revealed by pattern analysis of international multi-environment trials, Field Crops Research, 89:299-318.

Bhargava,A., S.Shukla and D.Ohri. 2006. Chenopodium quinoaAn Indian perspective, Industrial Crops and Products, 23:7387.

Bhargava,A., S.Shukla and D.Ohri. 2007. Genetic variability and interrelationship among various morphological and quality traits in quinoa (Chenopodium quinoa Willd.), Field Crops Research, 101:104-116.

Comai,S., A.Bertazzo, L.Bailoni, M.Zancato, C.V.L.Costa and G.Allegri. 2007. The content of proteic and nonproteic (free and protein bound) tryptophan in quinoa and cereal flours, Food Chem. 100:1350-1355.

Doweidar,M.M. and A.S.Kamel. 2011. Using of quinoa for production of some bakery products (gluten-free), Egyptian J. Nutrition, 26(2):21-52.

Erley,G.S., H.P.Kaul, M.Kruse and W.Aufhammer. 2005. Yield and nitrogen utilization efficiency of the pseudocereals amaranth, quinoa, and buckwheat under differing nitrogen fertilization, European Journal of Agronomy. 22 (1): 95-100. 
Finck,A. 1982. Fertilizer and fertilization "Introduction and practical guide to crop fertilization". Weinheim; Deerfield Beach, Florida; Basel: Verlag Chemie. ISBN 3-527-25891-4 (Weinheim).

Gomaa,E.F. 2013. Effect of nitrogen, phosphorus and biofertilizers on quinoa plant, Journal of Applied Sciences Research, 9(8):5210-5222.

Ince Kaya,Ç. 2010, Effects of various irrigation strategies using fresh and saline water applied with drip irrigation system on yield of quinoa and salt accumulation in soil in the Mediterranean region and evaluation of saltmed model, MSc. Thesis, Çukurova Univ., Inst. of Natural and Applied Sci., Dept. of Agricultural Structures and Irrigation,122p.

Jacobsen,S.E. 2003. The worldwide potential for quinoa (Chenopodium quinoa Willd.), Food Rev. Int. 19(1-2):167177.

Jacobsen,S.E., I.Jørgensen and O.Stølen. 1994. Cultivation of quinoa (Chenopodium quinoa) under temperate climatic conditions in Denmark, J. Agrc. Sci. 122: 47-52.

Kakabouki,I., D.Bilalis, A.Karkanis, G.Zervas, E.Tsiplakou and D.Hela. 2014. Effects of fertilization and tillage system on growth and crude protein content of quinoa (Chenopodium quinoa Willd.): An alternative forage crop, Emir. J. Food Agric., 26(1):18-24.

Kuhn,M., S.Wagner, W.Aufhammer, J.H.Lee, E.Kübler and H.Schreiber. 1996. Einfluß von pflanzenbaulicher Maßnahmen auf die Mineralstoffgehalte von Amaranth, Buchweizen, Reismelde und Hafer. Dt Lebensm Rundschau, 92:147-152.

Miranda,M., A.Vega-Gálvez, E.A.Martínez, J.López, R.Marín, M.Aranda and F.Fuentes. 2013. Influence of contrasting environments on seed composition of two quinoa genotypes: Nutritional and functional properties, Chilean Journal of Agricultural Research, 73(2):108-116.

Pearsall,D.M. 1992. The origins of plant cultivation in South America. In: C.W.Cowan, P.J.Watson (Eds.), The Origins of Agriculture. Smithsonian Institute Press, Washington, DC, pp:173-205.

Rea,J., M.Tapia and A.Mujica. 1979. Prácticas agronómicas. In: Quinoa y Kaňiwa, Cultivos Andinos, pp:83-120. Tapia,M., H.Gandarillas, S.Alandia, A.Cardozo and A.Mujica. (eds.). FAO, Rome, Italy.

Rojas,W., P.Barriga and H.Figueroa. 2003. Multivariate analysis of genetic diversity of Bolivian quinoa germplasm. Food Rev. Int., 19:9-23.

SAS Institute. 1998. INC SAS/STAT user's guide release 7.0, Cary, NC, USA.

Shams,A.S. 2012. Response of quinoa to nitrogen fertilizer rates under sandy soil conditions, Proc. $13^{\text {th }}$ International Conf. Agron., Fac. of Agric., Benha Univ., Egypt, 9-10 September 2012, p:195-205.

Simmonds,N.W. 1971. The breeding system of Chenopodium quinoa. I. Male Sterility, Heredity, 27:73-82.

Stell,R.G.D., J.A.Torrie and D.A.Dickey. 1997. Principles and Procedures of Statistics. A.Biometrical Approach $3^{\text {rd }}$ Edi. Mc Graw Hill Book. INC. NY.

Thanapornpoonpong,S. 2004. Effect of nitrogen fertilizer on nitrogen assimilation and seed quality of amaranth (Amaranthus spp.) and quinoa (Chenopodium quinoa Willd), Doctoral Dissertation, Doctor of Agricultural Sciences of the Faculty of Agricultural Sciences, Institute of Agricultural Chemistry, Georg-August-University of Göttingen. 